\title{
INTRODUCTORY REMARKS ON THE STRATIFICATION OF BORROWINGS THROUGH THE WORK OF MARY SERJEANTSON
}

\begin{abstract}
This paper examines the area of borrowings, the definition of borrowing as a process, the broader debate on the conditions of borrowing, reasons for borrowing describing both linguistic and extralinguistic aspects, the stratification of borrowings with its subclasses and consequent terminology. All of these issues are debated on the basis of the work of Mary Serjeantson.

Key words: borrowing, loanword, typology, extralinguistic factor, diachronic perspective
\end{abstract}

\section{Introduction}

The English language in general, and its lexis specifically, have been expanding through the process of borrowing. This particular enlargement of English vocabulary, in contrast to the previous periods, has not had such an impact as it used to have in the past, for instance in the Middle English period. However, as defined by David Crystal, "English has been open to a huge number of borrowings and it seems to have far more words in its vocabulary than other languages" [4, p. 42]. That is why it is of importance to deal with the linguistic stratification of borrowings and their definition as well.

\section{Borrowing and extralinguistic factors}

Interestingly, it was already in the 1930s when Mary Serjeantson stated in the initial part of her book related to the problematic of the foreign element in English that "the English language has throughout its history accepted with comparative equanimity words from other languages with which it has been in contact, and though there have been periods during which speakers and writers of English have made use of foreign words to an exaggerated extent, it is probable that most people will agree that the foreign element in normal English usage has been of value" [9, p. 1]. This introductory statement brings a concerned reader to at least two significant points that fit the area of interest of present-day linguists as well. The first of them is the importance of language contact that has been under a more thorough focus in the recent years under the title contact linguistics [cf. 11], while the second one refers to the value of the foreign element in the history and present-day state of the English language [cf. 3]. With respect to the former point of the language contact, M. Serjeantson specifies, in her own typology, several extralinguistic factors that have been playing a crucial role in the history of the foreign element within the English lan- guage or a language in general /a more up-to-date theoretical debate on the issues of extralinguistic reality and extralinguistic factors in general can be seen for example in: [6], [10] and [5].

The first extralinguistic phenomenon of the aforementioned typology describes the situation in which two different languages meet under certain circumstances and it is the number or quantity of speakers, one in majority and the other one in minority, which plays a significant role in the context of borrowing. As Serjeantson specifies, "when one nation subdues another which speaks a different language, the conquerors, if their object has been political power rather than settlement, may constitute an authority, or ruling class, which is from the point of view of numbers, much in the minority with the whole body of the conquered people. In case like this, it is usually the native language that survives, though the incoming dialect will very probably transfer to the native vocabulary words which express its own methods of government, and other cultural words" [9, pp. 1-2]. As Serjeantson adds, the epoch of NormanFrench in England is a suitable example for this extralinguistic characterology. However, with respect to this specification it must be noted that the number of the Norman-French was, despite the majority English element, growing considerably during the Middle English period [cf. 2].

The second factor of the typology, as put by M. Serjeantson, refers to the opposite situation where "the conquered country or province does not become an independent state under its new rulers, but is controlled by the original government, so that the ruling class is in constant contact with, and continually reinforced by, people speaking their own language, it has usually happened that the dialect of the rulers has won the day, and has spread throughout the community, absorbing some words from the native speakers, chiefly such as concern local products, natural features, etc., but without necessarily undergoing radical changes in itself" $[9$, p. 2]. However, this example of the typology is illustrated by Ser-

\footnotetext{
* Dalibor Mikulas

Department of English Language and Literature, Faculty of Science, University of Zilina, Slovakia, E-mail: dalibor.mikulas@fpv.uniza.sk
} 
jeantson in a different context than the English one, i.e. by the relative position of the Romans in Gaul where Latin absorbed a relatively small amount of the native Gaulish dialect words and thus became established.

The third factor of the typology points again to the Englishspeaking context and historical experience. M. Serjeantson claims that "a different set of circumstances arises when the invasion is for the purpose of settlement or colonization rather than merely for the sake of political power. If the newcomers arrive in such numbers as to form a majority over the native speakers, and in such military or political strength as to acquire complete control over these, or dispossess them, the dialect of the conquerors or colonists will have the upper hand from the start, wherever they establish themselves. They will, however, adopt from the natives whom they displace words which denote native products, etc., and occasionally native customs, which may have been unfamiliar before" $[9$, pp. 2-3]. Upon the given situation, the arrival of Anglo-Saxons to England and the consequent development of Old English could be seen as a clear example.

The fourth aspect of her diachronic perspective refers to the last centuries of Old English period and particularly to the language contact with the Norsemen or in other words with the Scandinavian element. As it is provided by M. Serjeantson, "sometimes warfare aiming at conquest results in a type of immigration, rather than colonization, as in the case of the Scandinavians in this country, where conflict led finally to more or less peaceful settlement, where the invaders established themselves side by side with the natives without overwhelming them or driving them out, and where the race, customs, and even the language, of the two peoples were sufficiently alike to make intercourse between the two, and the subsequent bilingualism, easy and natural" [9, p. 3]. Here, besides speaking about borrowings, this epoch of the language contact is also of a rather high level of importance in relation to the development of the present-day analytical character of the English language, mainly when analyzing the consequent loss of inflectional endings that were the point of difference between the English and Scandinavian languages at the turn of the Old English and Middle English periods, and thus these inflectional endings were, as some scholars assume, left out to ease the mentioned communication [cf. 2, p.157].

The fifth factor regarding the importance of extralinguistic phenomena in the study of borrowings refers, according to M. Serjeantson, to such contexts as can be seen for instance in American English and the immigrant experience. "If the immigrants come in a large enough body to form a small community of their own within the greater one, they are likely to retain their own speech, for a time at least, even though eventually yielding to the pressure of the language spoken all about them" [9, p. 3]. There are many examples of this type of the communities which came to the U.S. /e.g. Germans, Jews, etc./, preserved their own language, but gradually have been losing it /for a better understanding of this phenomenon illustrated on the basis of the Slovak immigrant experience in the US and consequently American English, see [8]/. In spite of this, it was these communities that influenced the language of the majority so that the language of the majority finally absorbed some of the foreign elements from the lexis of the aforementioned communities.

Finally, as it can be summarized in accordance with M. Serjeantson's diachronic concept from the 1930s, there is the sixth extralinguistic factor of a rather significant value for the English language in the area of borrowing, and that is a merchant-adventurer issue, or in simpler terms the phenomenon of trade. "For the English speakers, trade has always been an important factor in the introduction of new words and of new ideas. Even before English had separated from its Germanic stock it was trade almost as much as conquest which brought into it its first words from other languages [...]. In this respect trade and scientific exploration go hand in hand, and can hardly be separated; and the merchantadventurer holds an important place in the history of the English language" [9, pp. 3-4]. It is useful to add a comment that despite the fact that M. Serjeantson published this typology of hers in the first half of the 20th century, long before WWII, the issue of trade, besides the aforementioned phenomenon of conquest of any extend, bridges the gap between her period and the beginning of the $21 \mathrm{st}$ century, i.e. the global period of the Internet Age and Permanent Information Revolution.

\section{Stratification of borrowings defined by M. Serjeantson}

Given the above mentioned specifications, it may be stated that it was M. Serjeantson [9] who presented a systematic outline of extralinguistic phenomena playing an important role in the linguistic analysis of the problematic of borrowings. However, with respect to the stratification of borrowings, or - as defined in her own words - the loans, the analysis she presented is quite brief, pointing just to general subcategories. Thus we can state that according to the already defined and when paying attention to the given process of borrowing, M. Serjeantson [9] speaks about six, let us say, categories: loans, learned words, repeated loans, indirect borrowings, translation-loans, and loans whose clarification is later extended [cf. 11]. As she characterized, under the already mentioned extralinguistic phenomena, words are borrowed either in actual speech, or secondly, there are situations in which words are borrowed through the written language. A suitable example for this case of lexical borrowing could be seen on the role of Latin in the history of the English language "when English writers and translators took over, from Latin originals or models, Latin words to serve their purpose, sometimes retaining their original inflexions, sometimes using the appropriate English inflexion" [9, p. 4]. M. Serjeantson calls these words "learned words". They belong to such areas as science and literature, but the area of popular speech, too. As to the above mentioned third type of borrowings presented by her, it is in fact a word, either a popular, learned or technical one, which is borrowed from the same or different source more than once. These, the so-called "repeated loans", are represented in English in large numbers [9, pp. 4-5] and it may be even added that the given statement also deals with the diachronic point of view, i.e. the historical development of the English language when, 
for instance, English came into contact with the Latin language in the Old English period, then in the early period of Middle English it came into an extensive and massive contact with the French language and its varied dialects, and in the period of Renaissance again with Latin, Greek, French and other Romance languages.

The next M. Serjeantson's category of borrowing is the socalled "indirect borrowing", i.e. borrowing through an intervening language. Many words from the east integrated firstly in the early times to Greek, then to Latin and finally into English /e.g., pepper, camel, etc./. These indirect ways of borrowing were even more complex, involving more than three or four languages /e.g., elephant, albatross, apricot, etc./ [9, pp. 5-6].

A regular present-day subcategory of loanwords, the loan-translations, is characterized by M. Serjeantson as "translation-loans, especially common in case of compounds in the older periods of English, when a foreign word expressing a new idea is represented by the nearest equivalent of each of its elements, as when in Old English, for the Latin word uni-cornus, the English form an-horn /one-horn/, is coined..." [9, p. 10], or for the word evangelium the English variant god-spell /gospel/ was used.

Finally, as it is clear from the discussed source, it may be stated that borrowings at the beginning of their functioning can chiefly refer to the phenomena connected with the countries they come from, but later on these borrowings can extend their meaning in a wider perspective. Thus they construct another, separate subcategory, or in better words a phase through which they respond to the need of expressing the additional meaning. Truly, even the linguistic means arranged, for a certain time, in J. Algeo's regular column Among the New Words point to the true character of this Serjeantson's statement (see the extended sense of, for example, the word perestroika [1, pp. 244-245]).

\section{Conclusion}

The above typology of borrowings and their subcategories introduced by M. Serjeantson was later supplemented in a more exact and certainly a more elaborated manner by a number of distinguished scholars. So, this area needs to be further discussed in a more extended way, most suitably in some of the coming publications. Nevertheless, it is significant to take into consideration the fact that it was M. Serjeantson who, early in the 1930, contributed to the area of foreign elements in the English language with a careful analysis of loanwords.

\section{References:}

[1] ALGEO, J.: Where Do All the New Words Come from? American Speech, Vol 55, 4/1980, pp. 264-277, Available at: http://www.jstor.org.lib-proxy.nd.edu/journals/00031283.html,

[2] BARBER, CH.: The English Language: A Historical Introduction, Cambridge, Cambridge University Press, 2000

[3] CRYSTAL, D.: The Language Revolution, Cambridge, Polity Press, 2004

[4] CRYSTAL, D.: The English Language. A Guided Tour of the Language, London, 2002

[5] ONDRUS, P., HORECKY, J, FURDIK, J.: Contemporary Slovak Literary Language (in Slovak), Bratislava, Slovenske pedagogicke nakladatelstvo, 1980

[6] PEPRNIK, J.: Lexical Semantics, Rudiments of English Linguistics, Presov, Slovacontact, pp. 133-176, 2000

[7] PEPRNIK, J.: English Lexicology, Olomouc, Univerzita Palackeho v Olomouci, 2006

[8] PUCI, J.: A Few Notes on Some Aspects of Slovak Emigration to the U.S.A., Emigration to the English Speaking World, Ruzomberok, Catholic University Ruzomberok, pp. 119-127, 2006

[9] SERJEANTSON, M.: A History of Foreign Words in English, New York, Barnes\&Noble, Inc., 1961

[10] STEKAUER, P.: Essentials of English Linguistics, Presov, Slovacontact, 1993

[11] WINFORD, D.: An Introduction to Contact Linguistics, Malden, Oxford, Melbourne, Berlin, Blackwell Publishing Ltd., 2003. 